Article

\title{
Conservation Gaps in Traditional Vegetables Native to Europe and Fennoscandia
}

\author{
Kauê de Sousa ${ }^{1,2}$ (1) and Svein Øivind Solberg $1, * \mathbb{C}$ \\ 1 Department of Agricultural Sciences, Faculty of Applied Ecology, Agricultural Sciences and Biotechnology \\ Inland Norway University of Applied Sciences, 2318 Hamar, Norway; kaue.desousa@inn.no \\ 2 Bioversity International, 00054 Rome, Italy \\ * Correspondence: svein.solberg@inn.no; Tel.: +46-7354-01516
}

Received: 15 July 2020; Accepted: 3 August 2020; Published: 6 August 2020

check for updates

\begin{abstract}
Vegetables are rich in vitamins and other micronutrients and are important crops for healthy diets and diversification of the food system, and many traditional (also termed underutilized or indigenous) species may play a role. The current study analyzed 35 vegetables with a European region of diversity with the effort to map the conservation status in Fennoscandia and beyond. We mapped georeferenced occurrences and current genebank holdings based on global databases and conducted conservation gaps analysis based on representativeness scores in situ and ex situ. Out of the 35 target species, 19 got at a high priority score for further conservation initiatives, while another 14 species got a medium priority score. We identified a pattern where traditional vegetables are poorly represented in genebank holdings. This corresponds well to a lack of attention in the scientific community measured in number of published papers. Considering the grand challenges ahead in terms of climate change, population growth and demand for sustainability, traditional vegetables deserve greater attention. Our contribution is to provide a basis for conservation priorities among the identified vegetables species native to Fennoscandia.
\end{abstract}

Keywords: crop wild relatives; ecosystem services; ensemble models; genetic diversity; plant genetic resources; species distribution models

\section{Introduction}

The Russian scientist N.I. Vavilov linked crop diversity to region of domestication and established the concept of "centers of origin" [1], later termed "regions of diversity" [2]. To develop and maintain food production we need genetic diversity and in addition to a variety of cultivars and landraces, crop wild relatives represent such diversity. They can be gene sources for pest and disease resistance but also for more robust plants adapted to a more unpredictable climate [3-5]. Khoury et al. [6] pointed to conservation of genetic resources as a global concern; people consume food with genetic resources from outside their borders, often from other continents, so conservation and access to plant genetic resources is an international issue. Countries have committed themselves to safeguard genetic resources [7] and each country aims to map and conserve its diversity. Details on access are regulated under the International Treaty for Plant Genetic Resources for Food and Agriculture [8].

The northern part of Europe was not included in any of the centers proposed by Vavilov; however, Zeven and Zhukovsky [2] included a European-Siberian region of diversity, which covered Central-, Northern- and Eastern Europe, and Russia towards Mongolia and Kazakhstan. They linked several forage grasses and legumes, but also vegetables, herbs and spices, and fruit and berries to this region. As this is a huge region, we narrowed this paper to focus on vegetables, herbs and spices native to Fennoscandia. Fennoscandia is located between the Atlantic Ocean and Eurasia and includes Norway, Sweden, Denmark, Finland and a part of North-Western Russia. Precambrian granites and gneisses 
dominate the bedrock and boreal forest grow over large parts of the area and continues eastwards into Siberia [9]. High mountains in the west have a large impact on precipitation and there is a maritime climate in the west and a more continental in the east. Agriculture is located mostly along the coastline and in valleys but also in forests. Outlands are grazed by sheep and reindeer, and to a lesser extent by cattle.

Vegetables are among the plants especially important for healthy diets and food security [10]. Traditional vegetables (also termed underutilized or indigenous vegetables) represent a huge potential for diversification and are often grown in household gardens [11]. Such vegetables, or their wild ancestors, are present throughout Europe. The plants have been collected and domesticated and for many of the species cultivation has disappeared. For Fennoscandia, root and bulb plants were especially valuable as they could be stored and used during the long winter, but leaf vegetables were valuable too as they were used fresh during the summer [12]. Today, fresh vegetables are year-around commodities, but still local production and plant traditions are important. Promotion of recipes with local ingredients is popular, both as identity and as marketing a region or a country [13]. Furthermore, it is a way of appreciating local or indigenous knowledge. In Fennoscandia, we know that the Sami people collected plants, such as angelica (Angelica archangelica L.) and common sorrel (Rumex acetosa L.), and they later started to cultivate these vegetables [14].

Taking a bird's-eye view, one could argue that Fennoscandia and Northern Europe are not an important region for crop diversity, especially if compared to mega-centers, such as Central Asia, the Mediterranean and Latin America [15]. We still wanted to review Fennoscandia with a focus on vegetables, also including herbs and spices. Few studies have been carried out on such species from the region and we believe the region could harbor valuable genetic resources due to its northern location. The species in focus include both well-recognized crops and species that are partly domesticated or previously cultivated but forgotten today. We included annuals, biennials and perennials. Cultivation of most species came to Fennoscandia from the south or east, like the cultivation of carrot (Daucus carota L.) and beet (Beta vulgaris L.), which were domesticated in the Mediterranean, and asparagus (Asparagus officinalis L.), whose primary center of origin is on the salt-steppes of Eastern Europe or Western Asia [2]. These species are global vegetables today but have genetic resources present in Fennoscandia, also as wild or semi-wild populations. These populations are the northernmost in the world; thus, they may harbor valuable traits for breeding for crop adaptation.

Different approaches have been suggested for conducting gap analysis for genebanks. Focused Identification of Germplasm Strategy (FIGS) is one, and it works on the premise that adaptive traits in the material mirror the environmental conditions of their place of origin [16]. Diversity can be maximized by sampling accessions based on their geographic regions and collections could be built to cover a range of environments [17]. Another approach that shares some of the same premises is to use spatial analysis [18] but to include both ecological, geographical and sampling representativeness to calculate a final conservation score both in situ and ex situ [19]. For the present study we chose the latter approach.

As far as we know, no gap analysis of vegetables native to Europe and especially Northern Europe has been done. Work has been done on temperate grasses and pulses [20] and on crops with origin in other parts of the world, such as potato [21], cowpea [22], beans [23], eggplants [24], wild cucurbits [25] and wild chili pepper [19]. Traditional vegetables and their genetic resources have been promoted as important in tropical and subtropical regions [26,27] but seldom in regions such as Europe and Fennoscandia.

The current study aims at producing new insight into traditional Fennoscandian vegetables and their conservation status. We wanted to identify priority species and priority areas for germplasm collection missions, in order to safeguard diversity with a focus on Fennoscandia and beyond. We wanted to highlight the value of in situ conservation and to recognize genetic resources as an ecosystem service. We did not aim to attach economic value to such a service but just to pinpoint that plants growing in the forests and mountains are of interest not only for the local communities but also 
on a global scale as plants harbor traits of importance for future crop improvement and for increased resilience and diversification of our food systems.

\section{Materials and Methods}

\subsection{Selection of Target Species}

We selected target species on the basis of previous literature and on geographical criteria. One key source of information was the study of Zeven and Zhukovsky [2], who listed around 200 species belonging to the European-Siberian region of diversity (Table S1 (Supplementary Materials)). We categorized these species according to use and selected the vegetables, herbs and spices for further consideration. The next selection criterion was nativity to Fennoscandia. We used the Global Biodiversity Information Facility (GBIF) [28] and Mossberg and Stenberg [29] for this. We excluded Barbarea praecox R. Br. (winter cress), Valeriana locusta (L.) Betoke (lamb's lettuce), Mentha cardica Gerard ex Baker (Scotch mint), Sedum reflexum L. (Jenny stone crop), Bunium bulbocastanum L. (black zira), Portulaca oleracea L. (common purslane) and Rumex alpinus L. (Alpine dock) as they are not found in Fennoscandia. We also removed hybrids, such as Mentha $\times$ piperita L. and Mentha $\times$ rotundifolia (L.) Huds., due to taxonomic uncertainties in the wild populations of these hybrids. We ended up with 35 target species of vegetables that we could term Fennoscandian traditional vegetables (Table 1).

Table 1. Targeted Fennoscandian traditional vegetables with a European-Siberian region of diversity.

\begin{tabular}{|c|c|c|}
\hline Species (Common Name) & Annex $1^{A}$ & Comments on Use ${ }^{B}$ \\
\hline Allium ampeloprasum L. (Wild leek) & No & Bulbs used, previously cultivated \\
\hline Allium scorodoprasum L. (Sand leek) & No & Bulb used, previously cultivated \\
\hline Asparagus officinalis L. (Asparagus) & No & Young shoot harvested in spring \\
\hline Atriplex hortensis L. (Garden orache) & No & Leafy vegetable, previously cultivated \\
\hline Beta vulgaris L. (Beet) & Yes & Root crop, vegetable, sugar and fodder \\
\hline Brassica napus (L.) Mill. (Swede) & Yes & Root vegetable, also oil seed crop \\
\hline Brassica rapa L.(Turnip) & Yes & Root vegetable, also oil seed crop \\
\hline Campanula rapunculus L. (Bellflower) & No & Root and leafy vegetable \\
\hline Chaerophyllum bulbosum L. (Tuberous-rooted chervil) & No & Leafy vegetable, cultivation in decline \\
\hline Chenopodium album L. (Fat-hen) & No & Weedy plant, previously cultivated \\
\hline Chenopodium bonus-henricus L. (Allgood) & No & Leafy vegetable, previously a pot herb \\
\hline Chenopodium foliosum Asch. (Leafy goosefoot) & No & Leafy vegetable, previously cultivated \\
\hline Cichorium intybus L. (Chicory) & No & Leafy vegetable, roots also used \\
\hline Crambe maritima L. (Sea kale) & Yes & Leafy vegetable, previously cultivated \\
\hline Daucus carota L. (Carrot) & Yes & Root crop, commonly cultivated \\
\hline Lathyrus tuberosum L. (Groundnut peavine) & No & Tuber crops, flowers used for perfumes \\
\hline Nasturtium officinale R. Br. (Watercress) & No & Leafy vegetable \\
\hline Pastinaca sativa L. (Parsnip) & No & Root vegetable, wild types with sour root \\
\hline Peucedanum ostruthium Coch. (Master wort) & No & Root crop, previously cultivated \\
\hline Rumex acetosa L. (Garden sorrel) & No & Leafy vegetable, previously cultivated \\
\hline Rumex obtusifolius L. (Broad-leaved dock) & No & Leafy vegetable, previously cultivated \\
\hline Rumex patientia L. (Patience dock) & No & Leafy vegetable, previously cultivated \\
\hline Sanguisorba officinalis L. (Great burnet) & No & Leafy vegetable, rarely cultivated \\
\hline Angelica archangelica L. (Angelica) & No & Petioles, leaves and seeds used \\
\hline $\begin{array}{c}\text { Armoracia rusticana (Lamm.) Gaertner. Mey and } \\
\text { Scheb. (Horseradish) }\end{array}$ & Yes & Root crop, cultivated for its spicy taste \\
\hline Brassica nigra (L.) Koch. (Black mustard) & Yes & Seeds used to flavor food \\
\hline Carum carvi L. (Caraway) & No & Seeds used to flavor food \\
\hline Humulus lupulus L. (Hops) & No & Flowers cops used to flavor beer \\
\hline Levisticum officinale Koch. (Garden lovage) & No & Leafy herb, used for soups and salads \\
\hline Mentha spicata (L.) Huds. (Green mint) & No & Leafy aromatic plant, multiple uses \\
\hline Mentha suaveolens Ehrh. (Apple mint) & No & Leafy aromatic plant, multiple uses \\
\hline Myrrhis odorata (L.) Scop. (Garden myrrh) & No & Leafy herb, used as spice \\
\hline Origanum vulgare L. (Marjoram) & No & Leafy herb, used as spice \\
\hline Sanguisorba minor Scop. (Small burnet) & No & Leafy herb, multiple uses \\
\hline
\end{tabular}

${ }^{A}$ Annex 1 species under the International Treaty for Plant Genetic Resources in Food and Agriculture [8]. ${ }^{\mathrm{B}}$ Comments according to Zeven and Zhukovsky [2] and Høeg [12]. 
We categorized the species according to primary products used (leaf, bulb, tuber, root, stem, flower, seed), their cultivation status (widely cultivated, previously cultivated/rarely cultivated), and according to FAO's Annex 1 list of priority species for conservation under the International Treaty for Plant Genetic Resources in Food and Agriculture [8].

\subsection{Data Collection and Validation}

We surveyed the occurrences from The Global Biodiversity Information Facility (GBIF) [28], applying the scientific names and countries as filters in the search function. GBIF occurrences can be from natural populations, herbarium specimens, seed collections, or other records. The total number per species and clusters of georeferenced occurrences were compiled by using the map function of the GBIF website. The information was used to illustrate where natural populations are expected to be found. We surveyed the global ex situ genebank holdings using GENESYS online facility, the Global Gateway to Genetic Resources [30]. We applied the scientific names, countries of origin, and biological status of accessions as filters in the search functions and restricted the search to wild accessions only, comprising natural, semi-natural/wild, and semi-natural/sown. The top two provenience counties for each species were compiled from the summary function of the database as well as from the Fennoscandia countries Norway, Sweden, Finland and Denmark. A reported accession is a seed sample or another conserved propagation material unit maintained in genebanks that are reporting to GENESYS. Many genebanks, and especially the large ones, such as the Nordic genebank, report to the facility.

We then collated the occurrence data of the target species from both GBIF and GENESYS. Presence data from GBIF were programmatically downloaded using the R [31] package "rgbif" [32]. Presence data from GENESYS were downloaded manually from the web platform applying the filter "wild" on the biological status of the accession. For the data cleaning and filtering we applied the following criteria: (i) remove occurrences with missing geographical coordinates, or outside the reported administrative boundaries [33]; (ii) remove locations reported to be collected before 1960 to match with the baseline climate; (iii) remove locations from country centroids or with no decimals as it is a sign that these points were only taken at the country level and had low precision; (iv) re-assign coordinates located in coastal waters to their nearest location on the coastline using a 10 arc-min buffer; (v) remove duplicated records within the same grid cell at a 5 arc-min resolution [34].

For each target species, the relative importance of the target region (here Fennoscandia) was calculated. To further narrow down would be difficult due to lack of geo-references in the GENESYS ex situ conservation database. We therefore extracted the number of wild (natural, semi-natural or semi-wild) accessions with provenance in Norway, Sweden, Finland and Denmark in the database.

To track the number of scientific publications for the target species, we used the Web of Knowledge Core Collection [35]. The facility covers more than 12,000 international journals in the areas of the natural and social sciences and arts and humanities. We did not restrict our searches to any period, language or publication type and searched for the scientific names (with AND between genus and species) with the topic (TS command). The topic in Web of Science includes words from titles, abstracts and key words. Thus, topic will always catch a higher number of records than title searches.

\subsection{Climate Data}

We used WorldClim v1.4 [36], a dataset with climatic variables corresponding to a near-current climate ( 1960-1990) at a spatial resolution of 2.5 arc-min. To reduce bias in the model predictions we applied an analysis of variance-inflation factors (VIF) selecting the least correlated variables (VIF < 10). This process resulted in twelve variables: (i) bio02, mean diurnal temperature range; (ii) bio04, temperature seasonality; (iii) bio08, mean temperature of the warmest quarter; (iv) bio09, mean temperature of driest quarter; (v) bio15, precipitation seasonality; (vi) bio18, precipitation of warmest quarter; (vii) bio19, precipitation of coldest quarter; (viii) srad05, solar radiation $\left(\mathrm{kJ} \mathrm{m}^{-2} \mathrm{day}^{-1}\right.$ ) 
in May; (ix) srad12, solar radiation $\left(\mathrm{kJ} \mathrm{m}^{-2} \mathrm{day}^{-1}\right)$ in December; $(\mathrm{x})$ vapr07, water vapor pressure in July (kPa); (xi) wind07, wind speed $\left(\mathrm{m} \mathrm{s}^{-1}\right)$ in July; and (xii) wind speed $\left(\mathrm{m} \mathrm{s}^{-1}\right)$ in December.

\subsection{Data Analysis}

The distribution of the target species was modeled within longitudes -25 and -60 and latitudes 34 and 71. The analyses were performed in R [31,37] applying an ensemble method for species distribution modeling (SDM) implemented by the R package "BiodiversityR" [38]. The procedure consists in calculating the suitability as a weighted average of all probabilities predicted by the SDM algorithms [39] following three steps: (i) calibrate the models by assessing the performance of all SDM algorithms in a 10-fold cross-validation and computing the area under the curve (AUC) [40-42]; (ii) retain the algorithms that contributed at least $5 \%$ to the whole ensemble of models measured with the weighted AUCs from each algorithm; (iii) generate the suitability maps using the predictions from the selected algorithms in step 2. To generate the presence-absence maps, we converted the ensemble suitability from step 3 using the threshold of maximum specificity + maximum sensitivity [43]. In Figure S1 (Supplementary Materials) we show the AUC values for the selected algorithms for each ensemble of the target species.

\subsection{Gap Analysis}

For the gap analysis we followed the methods described by Khoury et al. [19] using the $R$ package "GapAnalysis" [44]. Four scores were calculated for the ex situ and in situ conservation statuses. The sampling representativeness score (SRS), the geographic representativeness score (GRS), the ecological representativeness score (ERS) and the final conservation score (FRS). The metrics ranged from 0 to 100, where a score of 0 means a poor conservation state and 100 a well conserved state. For this we used the distribution models described in the previous section, with the records from GBIF and GENESYS.

The SRS ex situ provides a general indication on how comprehensive are the collections in genebanks. This compares the total number of reported germplasm accessions $(G)$ available in GENESYS against the number of referenced $(\mathrm{H})$ records in GBIF, were an ideal ratio would be of 1:1. We used all references from GBIF and germplasm records from GENESYS, regardless of the existence of geographical records. The GRS ex situ measures the proportion of the geographical range comprised by the species distributions that are conserved in genebanks. We created buffers of 0.5 arc-degrees for each genebank collection and estimated the areas where genebank accessions were collected within the modeled geographical range of species. The ERS ex situ assesses the proportion of ecoregions that are represented in the genebank collections. Ideally a species is well conserved when it has reported collections for every potential ecoregion covered by its geographical distribution. To estimate this index we used the TNC (The Nature Conservancy) terrestrial ecoregions [45]. We obtained the ex situ final conservation score (FCS ex situ) by taking the average of the previous ex situ metrics.

To assess the in situ conservation we applied the four metrics described previously focusing on the state of conservation of the target species within officially protected areas. In situ conservation maintains genetic variation in its natural environments. The current system with nature reserves and national parks tends to focus on habitats or ecosystems rather than specific plant genetic resources. However, plant genetic resources may also be found outside protected areas. Thus, we should be aware that limiting the analysis of in situ conservation to officially recognized protected areas may constitute only a fraction of the biodiversity found in situ. We used the World Database of Protected Areas (WDPA) [46], selecting all terrestrial and coastal protected areas within the study region. For the SRS in situ we computed the proportion of GBIF occurrences that falls within the protected areas. For the GRS in situ we compared the proportion of area of the modeled distribution for each species that are covered by a protected area. For the ERS in situ compares the variation in ecoregions that comprises the distribution range of each species within the protected areas. The in situ final conservation score for in situ (FCS in situ) was computed by taking the average of the previous in situ metrics. We computed the 
Final Conservation Score by averaging all ex situ and in situ scores. As applied by Khoury et al. [19], we categorized the final conservation score in priority for further conservation accordingly: (i) high priority when scoring $<25$; (ii) medium priority when scoring $\geq 25$ to $<50$; low priority when scoring $\geq 50$ to $<75$; and (iv) sufficiently conserved when scoring $\geq 75$.

\subsection{Supporting $R$ Packages}

To organize the datasets the R packages "data.table" [47], "magrittr" [48], "janitor" [49], "Taxonstand" [50] and "tidyverse" [51] were used. We processed the layers using the packages "sp" [52], "sf" [53], "maptools" [54], "raster" [55], "rgdal" [56], "dismo" [57], "alphahull" [58], "rJava" [59] and "rgeos" [60]. The maps were produced using the packages "ggplot2" [61] and "patchwork" [62].

\section{Results}

\subsection{Georeferenced Occurrences}

A total number of 3,105,406 georeferenced occurrences was reported in GBIF for the 35 targeted vegetable species that have a European-Siberian region of diversity. The highest number of occurrences were for garden sorrel (Rumex acetosa L.), carrot (Daucus carota L), broad-leaved dock (Rumex obtusifolius L.) and fat-hen (Chenopodium album L.). At the other end and with the lowest number of occurrences (5000 or less per species) were leafy goosefoot (Chenopodium foliosum Asch.), garden lovage (Levisticum officinale Koch.), garden orache (Atriplex hortensis L.), patience dock (Rumex patientia L.) and master-wort (Peucedanum ostruthium (L.) Coch.).

A diversity map showed that Denmark, Germany, the Netherlands, Belgium and parts of the UK and France had all 35 target species and that the southern part of Fennoscandia had a higher number of the species than the northern and eastern parts of the region (Figure 1).

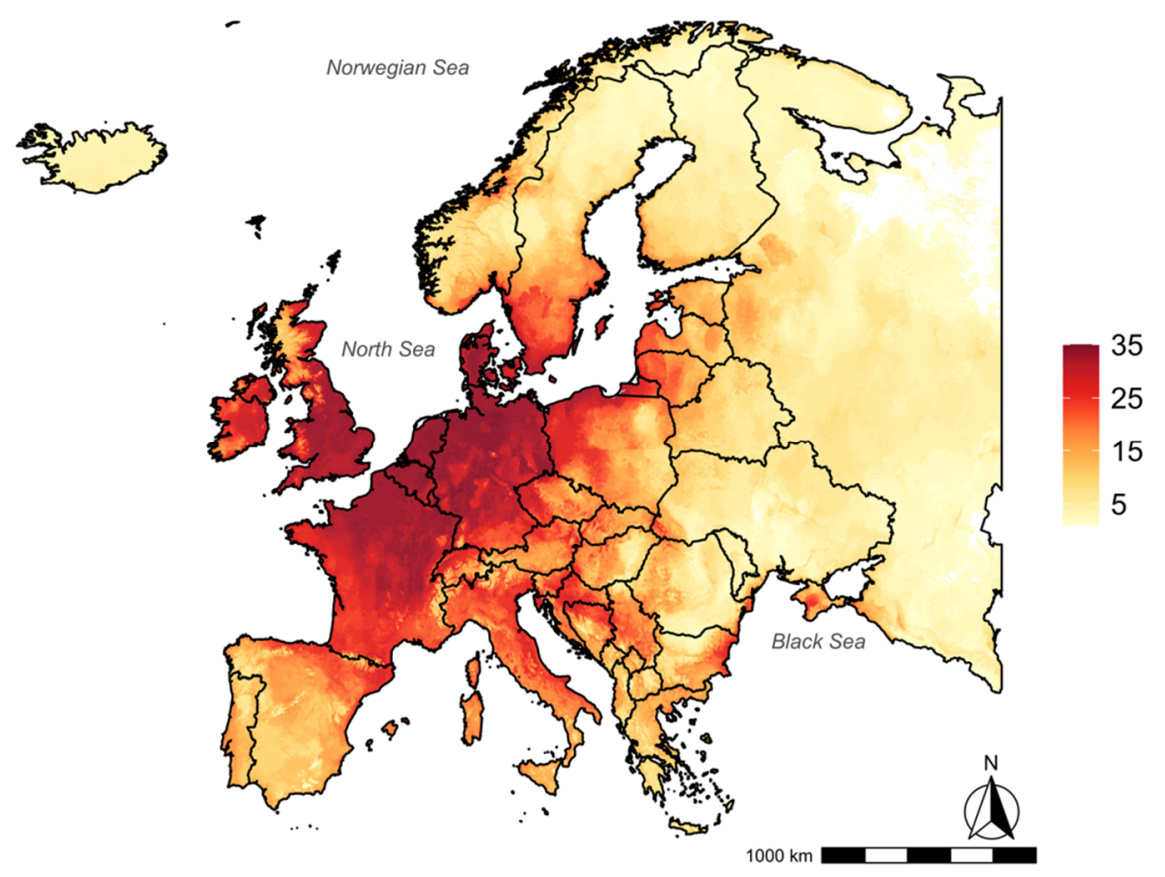

Figure 1. Predicted species richness combining the 35 traditional vegetables across Europe based on the ensemble of species distribution models. The color gradient, from yellow to dark red, represents the suitability of a given species per grid-cell ( 2.5 arc-min).

Northern Europe, including Fennoscandia, was a cluster for master-wort and angelica (Angelica archangelica L.), while Northern/Western Europe were main clusters for turnip (Brassica 
rapa L.) and sea kale (Crambe maritima L.). Central and Northern European clusters were detected for garden lovage, garden orache, sand leek (Allium scorodoprasum L.), tuberous-rooted chervil (Chaerophyllum bulbosum L.), garden myrrh (Myrrhis odorata (L.) Scop.) and caraway (Carum carvi L.). For the rest of the target species Northern Europe with Fennoscandia were present with occurrences but more as in the periphery of the distribution clusters (Figures 2 and 3).
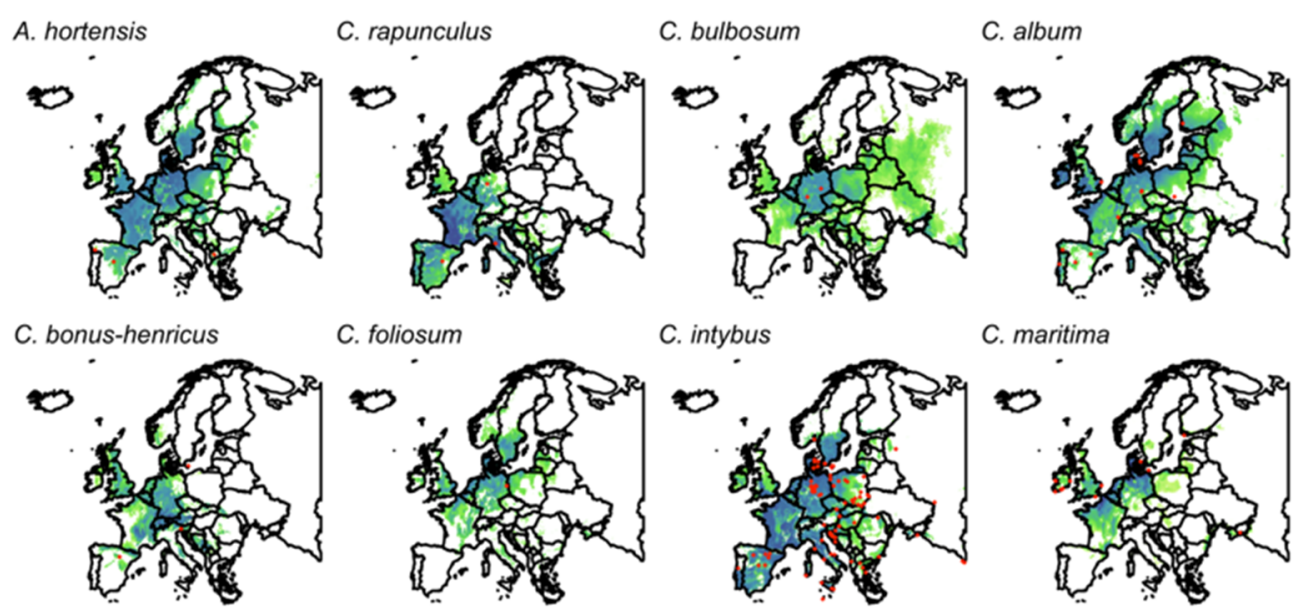

C. maritima
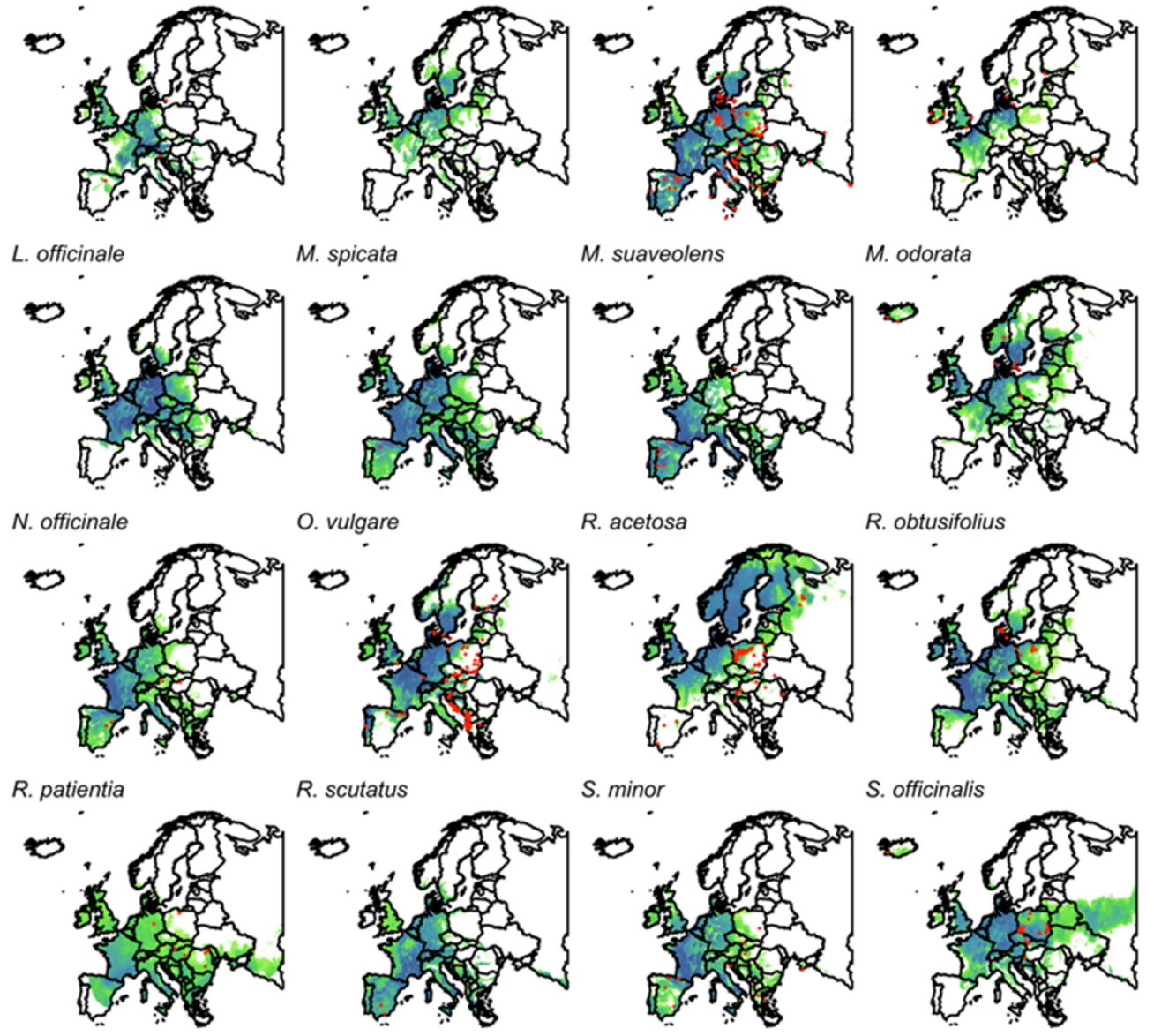

Figure 2. Suitability of the 20 targeted leafy traditional vegetables across Europe. The color gradient, from yellow to dark blue, represent the suitability of a given species per grid-cell (2.5 arc-min). Red dots represent the locations where wild/natural accessions have been collected, georeferenced, stored in a genebank and reported to GENESYS. 

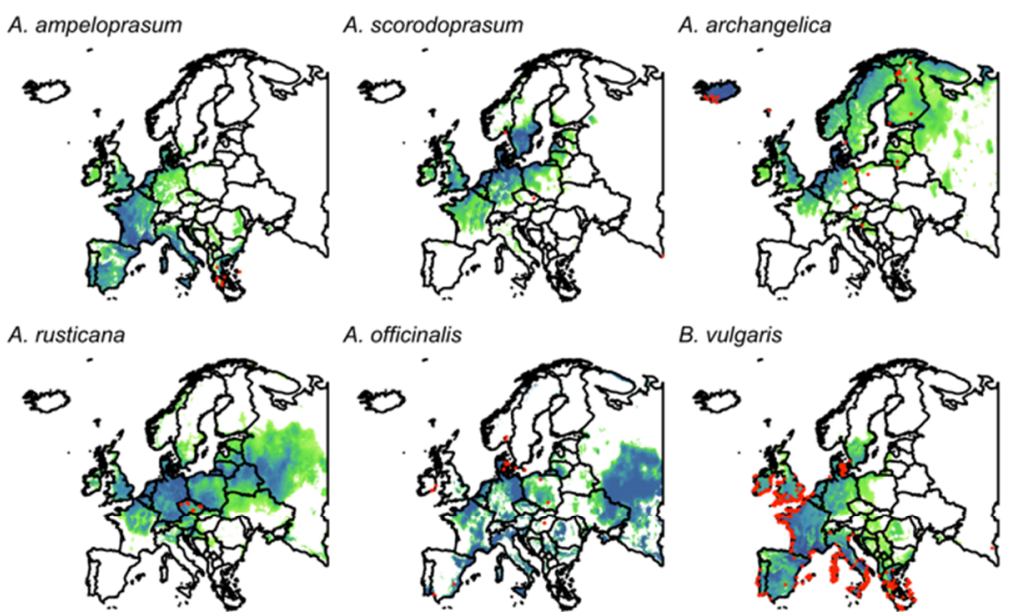

B. vulgaris
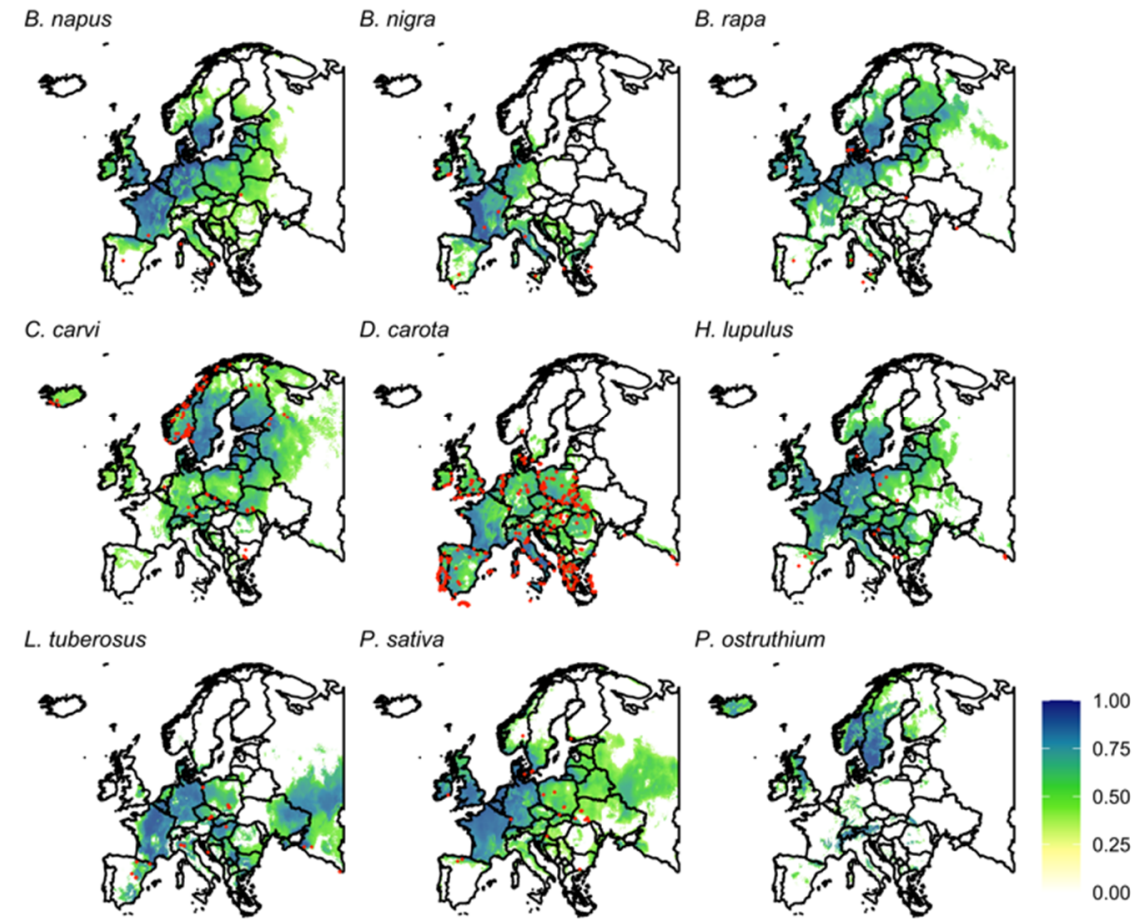

Figure 3. Suitability of the 15 targeted root, bulb, stem and flower traditional vegetables across Europe. The color gradient, from yellow to dark blue, represent the suitability of a given species per grid-cell (2.5 arc-min). Red dots represent the locations where wild/natural accessions have been collected, georeferenced, stored in a genebank and reported to GENESYS.

\subsection{Genebank Holdings and Ex Situ Conservation Gaps}

A total of 39,541 accessions were found in GENESYS for the targeted 35 vegetables and of these 5968 were classified as wild (including wild/natural and semi-wild/semi-natural). Furthermore, less than $64 \%$ of these wild accessions were georeferenced, with an average of $53 \%( \pm 27 \%)$ georeferenced accessions per species. The provenance countries of the accessions are provided in Table 2. 
Table 2. Overview of georeferenced GBIF occurrences of target species with the main cluster of occurrences and the total number of records in GBIF. In addition, as overview of the total number of accessions in genebank holdings GENESYS and how many of these that are classified as wild (natural, semi-natural or semi-wild), and again how many of these wild accessions are from Norway (NOR), Sweden (SWE), Finland (FIN) and Denmark (DEN). In brackets are the number of georeferenced accessions.

\begin{tabular}{|c|c|c|c|c|c|c|c|c|}
\hline \multirow{2}{*}{ Species } & \multicolumn{2}{|c|}{ GBIF Occurrences } & \multicolumn{6}{|c|}{ GENESYS (Ex Situ Conserved Accessions) } \\
\hline & Cluster & Total & Total & Wild & NOR & SWE & FIN & DEN \\
\hline Allium ampeloprasum & $\mathrm{C}+\mathrm{N}$ Europe & 11,841 & $869(226)$ & $147(31)$ & 0 & 0 & 0 & 0 \\
\hline Allium scorodoprasum & $\mathrm{C}+\mathrm{N}$ Europe & 16,197 & $35(5)$ & $24(10)$ & $1(1)$ & 0 & 0 & 0 \\
\hline Angelica archangelica & N Europe & 30,784 & $139(74)$ & $71(46)$ & $1(0)$ & $4(1)$ & $12(12)$ & $2(1)$ \\
\hline Armoracia rusticana & Europe & 34,447 & $168(20)$ & $15(10)$ & 0 & 0 & 0 & $2(0)$ \\
\hline Asparagus officinalis & Europe & 57,252 & $302(77)$ & $62(37)$ & $3(2)$ & $1(1)$ & 0 & $8(7)$ \\
\hline Atriplex hortensis & $\mathrm{C}+\mathrm{N}$ Europe & 2815 & $299(98)$ & $31(5)$ & 0 & $2(0)$ & 0 & 0 \\
\hline Beta vulgaris & Europe & 46,667 & $\begin{array}{c}8826 \\
(1600)\end{array}$ & $\begin{array}{c}1324 \\
(1016)\end{array}$ & 0 & $1(1)$ & 0 & $42(7)$ \\
\hline Brassica napus & Europe & 34,438 & $\begin{array}{l}8410 \\
(408)\end{array}$ & $93(13)$ & 0 & 0 & 0 & 0 \\
\hline Brassica nigra & Europe & 22,998 & $726(96)$ & $102(65)$ & 0 & 0 & 0 & $1(0)$ \\
\hline Brassica rapa & $\mathrm{W}+\mathrm{N}$ Europe & 27,724 & $\begin{array}{c}7655 \\
(1038)\end{array}$ & $182(31)$ & 0 & $1(1)$ & 0 & $4(4)$ \\
\hline Campanula rapunculus & Europe & 70,183 & $47(18)$ & $41(28)$ & 0 & 0 & 0 & 0 \\
\hline Carum carvi & $\mathrm{C}+\mathrm{N}$ Europe & 61,961 & $473(149)$ & $244(98)$ & $59(42)$ & $2(1)$ & $12(3)$ & $3(0)$ \\
\hline Chaerophyllum bulbo. & $\mathrm{C}+\mathrm{N}$ Europe & 18,752 & $29(2)$ & $17(9)$ & 0 & 0 & 0 & 0 \\
\hline Chenopodium album & Europe & 264,036 & $163(46)$ & $98(67)$ & 0 & 0 & $2(1)$ & $7(4)$ \\
\hline Chenopodium bonus- $h$. & C Europe & 19,660 & $24(6)$ & $5(3)$ & 0 & 0 & 0 & $1(1)$ \\
\hline Chenopodium foliosum & C Europe & 2087 & $15(5)$ & $7(4)$ & 0 & 0 & 0 & 0 \\
\hline Cichorium intybus & Europe & 104,789 & $\begin{array}{l}1137 \\
(266)\end{array}$ & $302(229)$ & $1(1)$ & $3(3)$ & 0 & $9(6)$ \\
\hline Crambe maritima & W Europe & 12,710 & $48(16)$ & $41(22)$ & 0 & $6(0)$ & $1(1)$ & $1(1)$ \\
\hline Daucus carota & Europe & 364,475 & $\begin{array}{c}6085 \\
(1389)\end{array}$ & $\begin{array}{c}1298 \\
(1041)\end{array}$ & $3(1)$ & $7(3)$ & 0 & $12(7)$ \\
\hline Humulus lupulus & C Europe & 177,294 & $\begin{array}{l}2725 \\
(277)\end{array}$ & $651(356)$ & 0 & 0 & 0 & $2(1)$ \\
\hline Lathyrus tuberosum & $\mathrm{C}+\mathrm{E}$ Europe & 34,197 & 0 & 0 & 0 & 0 & 0 & 0 \\
\hline Levisticum officinale & $\mathrm{C}+\mathrm{N}$ Europe & 2697 & $80(13)$ & $10(0)$ & 0 & 0 & 0 & 0 \\
\hline Mentha spicata & Europe & 20,081 & $242(58)$ & $66(9)$ & 0 & 0 & 0 & 0 \\
\hline Mentha suaveolens & Europe & 59,784 & $73(17)$ & $18(14)$ & 0 & 0 & 0 & $1(1)$ \\
\hline Myrrhis odorata & $\mathrm{C}+\mathrm{N}$ Europe & 18,799 & $37(14)$ & $19(19)$ & $2(2)$ & $4(4)$ & 0 & $2(2)$ \\
\hline Nasturtium officinale & C Europe & 80,137 & $82(50)$ & $62(50)$ & 0 & 0 & 0 & 0 \\
\hline Origanum vulgare & C Europe & 175,670 & $590(306)$ & $430(296)$ & 0 & $3(3)$ & $5(3)$ & $5(3)$ \\
\hline Pastinaca sativa & C Europe & 136,457 & $470(108)$ & $102(34)$ & $1(1)$ & $2(1)$ & $1(1)$ & $1(0)$ \\
\hline Peucedanum ostruthium & N Europe & 5027 & $25(23)$ & $20(4)$ & 0 & 0 & 0 & 0 \\
\hline Rumex acetosa & Europe & 604,991 & $234(5)$ & $168(102)$ & 0 & 0 & 0 & 0 \\
\hline Rumex obtusifolius & Europe & 358,346 & $44(12)$ & $39(38)$ & 0 & 0 & 0 & 0 \\
\hline Rumex patientia & C Europe & 3307 & $30(3)$ & $19(13)$ & 0 & 0 & 0 & 0 \\
\hline Rumex scutatus & C Europe & 22,798 & $23(18)$ & $16(8)$ & 0 & 0 & 0 & 0 \\
\hline Sanguisorba minor & C Europe & 133,060 & $242(38)$ & $174(65)$ & 0 & 0 & 0 & 0 \\
\hline Sanguisorba officinalis & Europe & 103,584 & $112(55)$ & $70(64)$ & 0 & 0 & 0 & 0 \\
\hline
\end{tabular}

GBIF, Global Biodiversity Information Facility; C, Central Europe; N, Northern Europe; E, Eastern Europe; W, Western Europe.

We next examined gaps in the ex situ conservation system of genetic resources of the target species as reported by GENESYS. First, groundnut peavine (Lathyrus tuberosum L.) had no single accessions in the database, neither of cultivated nor of wild types. Thereafter, leafy goosefoot, master-wort, allgood (Chenopodium bonus-henricus L.) and tuberous-rooted chervil had less than 30 accessions in total in GENESYS. Looking at the proportions of wild (wild/natural and semi-wild/semi-natural) compared to cultivated biological status of the material (commercial cultivars, landraces and breeding lines), a low representation of wild material (less than $3 \%$ of the total number of accessions) was detected for swede/rapeseed (Brassica napus (L.) Mill.) and turnip, followed by horseradish (Armoracia rusticana (Lamm.) Gaertner. Mey and Scheb.), garden orache, garden lovage and black mustard (Brassica nigra (L.) Koch.), all with 3-15\% wild accessions. At the other end, with more than $75 \%$ wild accessions, we found watercress (Nasturtium officinale R. Br.), great burnet (Sanguisorba officinalis L.), sea kale, Rampion bellflower (Campanula rapunculus L.) and broad-leaved dock.

A clear correlation $\left(R^{2}=0.74\right)$ was found between GENESYS records in the form of number of accessions per species and publication records at ISI Web of Science (Figure 4). The minor crops 
were poorly represented and the lowest number of publications were for groundnut peavine (four publications), garden myrrh (7), tuberous-rooted chervil (13), Rampion bellflower (16), leafy goosefoot (16), sand leek (21), sea kale (24) and allgood (25). Eleven species were represented with more than 800 publications each with swede/rapeseed (16,244 publications), beet (7788), turnip (4613) and carrot (3807) at the top followed by fat hen (2125), hops (Humulus lupulus L.) (1657), marjoram (Origanum vulgare L.) (1583), chicory (Cichorium intybus L.) (1567), asparagus (Asparagus officinalis L.) (1187), black mustard (857) and green mint (Mentha spicata (L.)) Huds. (804).

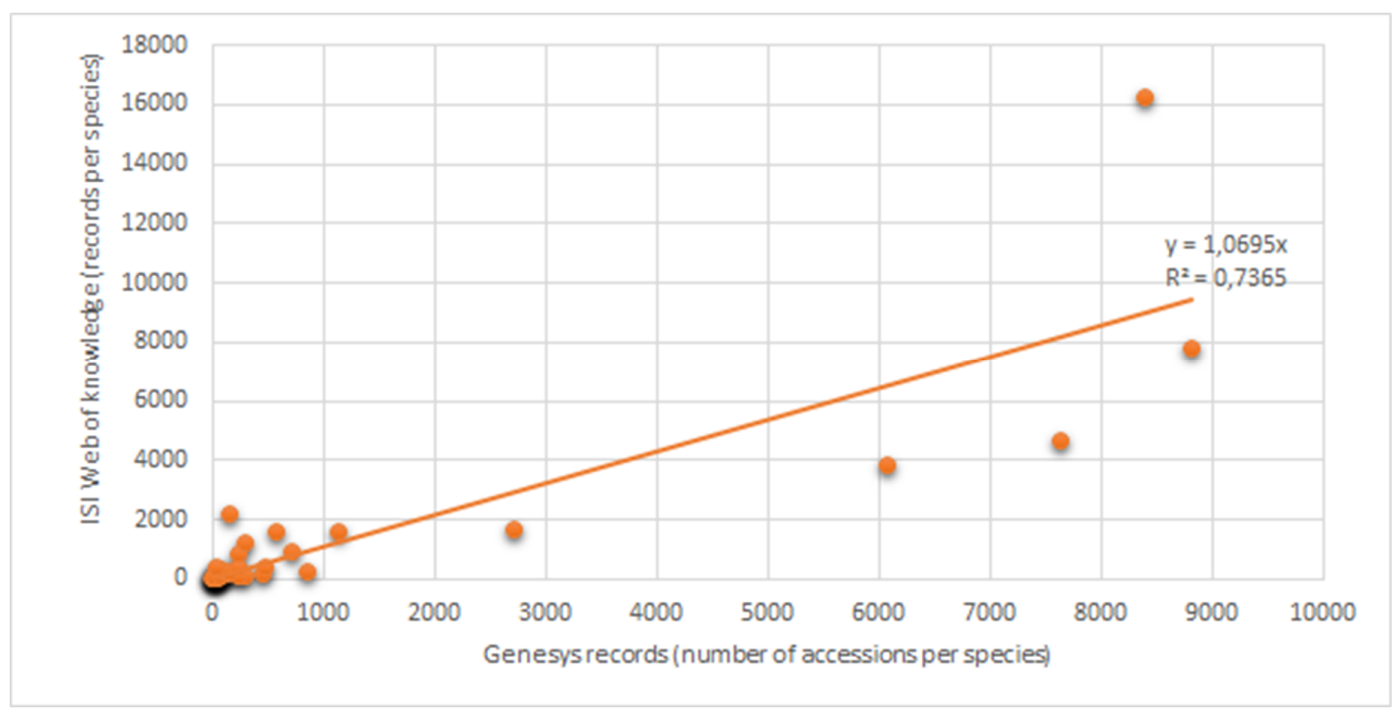

Figure 4. Graph showing the plots from number of ISI Web of Knowledge records and GENESYS records per species.

Looking closer at the Fennoscandia provenance, no wild accession from this region was detected in GENESYS for swede/rape, green mint, garden sorrel, leafy goosefoot, tuberous-rooted chervil, patience dock, small burnet (Sanguisorba minor Sp.), watercress, great burnet, master-wort, Rampion bellflower and broad-leaved dock. Species with a low representation from Fennoscandia, where less than $2 \%$ of the wild accessions in GENESYS were from Fennoscandia, were hops, turnip, black mustard and carrot. At the other end of the scale, beet, asparagus, parsnip, angelica, caraway and garden myrrh had a significant proportion of wild accessions from Fennoscandia.

\subsection{Conservation Status}

The analysis on the conservation gaps showed that 19 of the 35 target vegetables fell into the high priority category for Europe based on the final conservation score across in situ and ex situ scores as explained in the Materials and Methods section (Figure 5). Another 14 target species were scored within the medium priority category while only carrot and beet scored in the low priority category. 


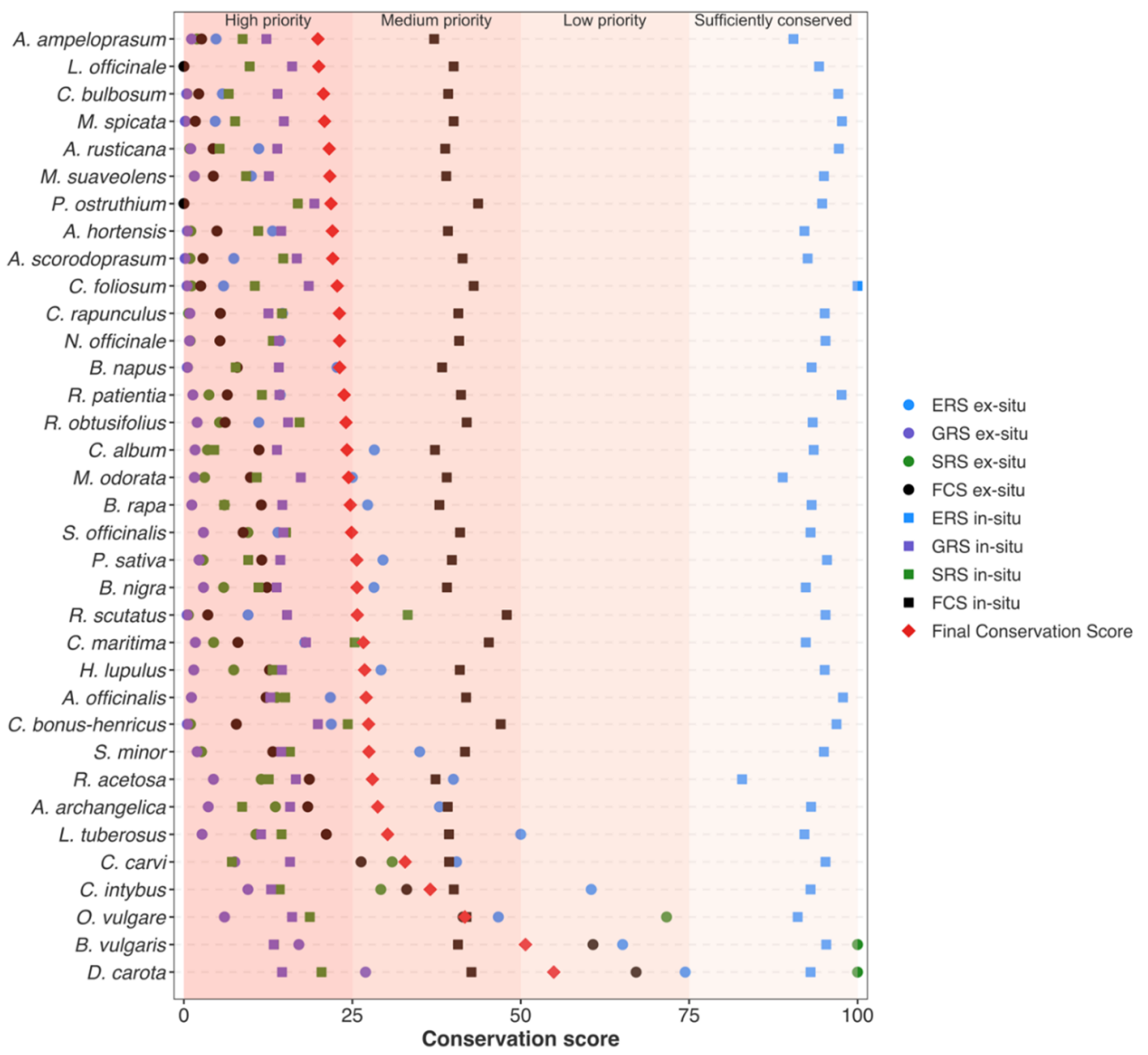

Figure 5. Conservation status of the 35 targeted traditional vegetables in Europe based on in situ and ex situ conservation representativeness scores. Species are ordered based on the need of further conservation action, from high (top) to least (bottom). ERS, ecological representativeness score; GRS, geographical representativeness score; SRS, sampling representativeness score; FCS, final conservation score, based on the mean of ERS, GRS and SRS within each conservation category. Final conservation score is based on the mean of ERS, GRS, SRS across in situ and ex situ scores.

\section{Discussion}

Our point of departure was that conservation of plant genetic resources is a global concern where relevant scientific communities in each country need to take part. There are several uncertainties about the introduction of plants to Northern Europe as references are rare prior to the 16th century [63-65]. Plants may have been introduced but escaped from cultivation and now exist as semi-wild populations. We showed this pattern in the predicted species richness, where the higher diversity is found in northwestern Europe. We could regard such populations as part of our bio-cultural heritage, as they have survived for hundreds of years and thus have good traits for adaptation and hardiness. Many accessions have been safeguarded in ex situ genebanks, and wild plants continue to survive in situ, at least if their natural environments remain unchanged. Still, there is much to be done, especially for minor crops such as traditional vegetables.

With the gap analysis (Figure 5) we showed that only two out of the 35 target crops could be classified as low priority crops for further conservation. The low rate of georeferenced accessions reported to GENESYS ( $~ 53 \%$ per species) may limit our understanding on the full conservation status of the 35 target vegetables in Europe. Uncertainty remains whether the conservation score could be higher if all the sampled data were complete. This calls not only to prioritize collection missions for 
these species, specially the 19 with high priority, but also for best practices in reporting accessions and data management of existing information to prevent duplicated efforts in new collections.

There are different explanations to the result that many of our traditional target vegetables are poorly represented in genebanks. One explanation is that crops being minor or underutilized implies them not being in focus. One could argue that such crops have little value. Our results showed that the species with the highest number of publication records were those with the highest number of conserved accessions, and vice versa. Traditional vegetables on the high priority list, such as master-wort, leafy goosefoot and tuberous-rooted chervil, have no or very few accessions and this accounts for all genebanks reporting to GENESYS. The mentioned species are also relatively rare to find as wild populations (Table 2, Figure 1). Some details on a few of the species: master-wort (belonging to the Apiaceae) has been cultivated in Fennoscandia and used to flavor beverages or for medicinal purposes [66]. Recent research has identified bioactive constituents as different furanocoumarins [67]. The plant is said to have been introduced to Fennoscandia in mediaeval time. It is very rare to find today and grows in small populations in old meadows or close to farmhouses [68]. Few measures have been taken so far to conserve these populations. Leafy goosefoot was included in Rudbeck's Catalogus plantarum published in 1658 about Swedish wild or semi-wild plants [69]. It was previously cultivated as a leafy vegetable, but cultivation has disappeared. Today the plant is rare to find and most populations are in or close to cultivated landscapes and in the southern parts of Fennoscandia. Tuberous-rooted chervil (an Apiaceae) could be an alternative to potato and is rich in starch, with a dry matter content exceeding 35\% [70]. In France, tuberous-rooted chervil is considered a gourmet vegetable and initiatives have been made to extend cultivation by breeding varieties of the plant [71]. In Fennoscandia, the plant has most likely been introduced and is naturalized but rare, and most of these populations are found in the southern landscapes. A closely related species, often termed a subspecies C. prescottii, is widespread especially in northern areas of Fennoscandia and seems to have a Russian origin [72].

Other species on the high priority list were garden orache, garden lovage, sand leek, and the two Mentha species, green mint and apple mint (M. suaveolens Ehrh.), the latter with very limited distribution in Fennoscandia. Garden orache is known from the area since medieval times [69]. According to Linné [73], the plant was common as a weed but has now almost disappeared. Garden lovage was described as naturalized in Sweden in the 18th century but was also introduced to Fennoscandia.

Wild leek (Allium ampeloprasum L.), watercress, patience dock and Rampion bellflower are species at a high priority but very rare to find as wild populations in Fennoscandia. Horseradish and hops are common but are maintained in clonal archives. Such archives were established in the Nordic countries by the national programs for plant genetic resources, but they only maintain genotypes with a documented cultivation history and not wild/semi-wild plants [74]. Allgood and groundnut peavine got a medium final score. Up to the 19th century groundnut peavine was grown in Europe as a vegetable used for its edible tubers [75]. Now it is more of an ornamental plant but has potential for use in diversification of horticulture. Allgood (belonging to the Amaranthaceae) is another priority species. The plant has been used as a potherb and a medicinal plant. In Sweden, people used leaves against pancratium [76] and roots have been used to treat diarrhea and lung infections [77]. Today the plant is very rare in Fennoscandia and to our knowledge is in decline.

As our overview has shown, some species are poorly represented in genebanks. To conserve more than a few accessions per species is of great value, as different accessions may have different nutrient contents [78] as well as different adaptation traits. Thus, collects from Fennoscandia might have a special value in a global context. A few plants were domesticated in Fennoscandia, such as angelica, but the majority were introduced, most likely through trading routes and monasteries in medieval times [79]. Little is known about the details. However, it is documented that certain species tend to have their habitats at historical sites [80,81]. Ethnobotanical studies are relevant for understanding the distribution and use of plants. The targeted vegetables have been necessities used as food and spices but also for other purposes. For Fennoscandia the work of Høeg [12] is especially valuable 
for compiling traditional plant knowledge. For the eastern and southern parts of Europe the works of Pieroni, Soukand and Dogan are important [82-87]. Luczaj et al. [88] presented an overview of the changes in the contemporary use of wild food plants in Europe using examples from Poland, Italy, Spain, Estonia and Sweden. A general decline in use and knowledge has been identified across Europe. Our concern is that such a lack of knowledge may lead to lack of care. Habitat destruction is more likely to take place when knowledge is lacking. Indigenous people had ways to secure plant populations. They also used a wide range of species $[89,90]$. To start using our bio-cultural heritage is positive, as shown in the New Nordic Cuisine [13]. However, over-exploitation is a risk factor if wild species are commercialized without being put into agricultural production or a proper sustainable harvesting regime. Independent of today's situation, conservation of genetic resources is important for future generations.

\section{Conclusion}

We have demonstrated that traditional vegetable genetic resources are sparsely represented in genebank collections. A hundred years after Vavilov published his ideas on centers of origin, we still have a long way to go in Europe. Gaps have been identified. Traditional vegetables have a great potential for healthy diets, for diversification and for local innovation and food culture [11,91,92]. Conservation action and promotion of such crops should be carried out. The impacts of climate change on current habitats and current production systems are not fully understood $[3,93,94]$. The importance of diversity seems to be increasing.

Supplementary Materials: The following are available online at http://www.mdpi.com/2077-0472/10/8/340/s1. Table S1: Excel file with complete list of species with an European region of Diversity. Figure S1: Goodness-of-fit (area under the curve-AUC) of the ensemble algorithms selected for the species distribution model of the 35 target vegetable species.

Author Contributions: Conceptualization, K.d.S. and S.Ø.S.; methodology, K.d.S.; formal analysis, K.d.S; writing-original draft preparation, K.d.S. and S.Ø.S.; writing-review and editing, K.d.S. and S.Ø.S.; All authors have read and agreed to the published version of the manuscript.

Funding: This work was supported by Interreg Sweden-Norway, the European Regional Development Fund.

Acknowledgments: We would like to thank Matteo Dell'Acqua and our two reviewers for valuable comments on our manuscript.

Conflicts of Interest: The authors declare no conflict of interest. The funders had no role in the design of the study; in the collection, analyses, or interpretation of data; in the writing of the manuscript, or in the decision to publish the results.

\section{References}

1. Vavilov, N.I. The centers of origin of cultivated plants. Works Appl. Bot. Plant Breed. 1926, 16, 248.

2. Zeven, A.C.; Zhukovsky, P.M. Dictionary of Cultivated Plants and Their Centres of Diversity-Excluding Ornamentals, Forest Trees and Lower Plants; Centre for Agricultural Publishing and Documentation: Wageningen, the Netherlands, 1975; 219p.

3. McCouch, S.; Baute, G.J.; Bradeen, J.; Bramel, P.; Bretting, P.K.; Buckler, E.S.; Burke, J.M.; Charest, D.; Cloutier, S.; Cole, G.; et al. Feeding the future. Nature 2013, 499, 23-24. [CrossRef] [PubMed]

4. Betts, R.A.; Hawkins, E. Climate projections. In Plant Genetic Resources and Climate Change; Jackson, M., Ford-Lloyd, B., Parry, M., Eds.; CABI: Wallingford, UK; Boston, MA, USA, 2014; pp. 38-60.

5. Lin, B. Resilience in Agriculture through Crop Diversification: Adaptive Management for Environmental Change. BioScience 2011, 61, 183-193. [CrossRef]

6. Khoury, C.K.; Achicanoy, H.A.; Bjorkman, A.; Navarro-Racines, C.; Guarino, L.; Flores-Palacios, X.; Engels, J.M.M.; Wiersema, J.H.; Dempewolf, H.; Sotelo, S.; et al. Origins of food crops connect countries worldwide. Proc. R. Soc. B Biol. Sci. 2016, 283, 20160792. [CrossRef]

7. Convention of Biodiversity. Available online: https:/www.cbd.int/convention/text/ (accessed on 14 July 2020).

8. International Treaty on Plant Genetic Resources for Food and Agriculture; Food and Agriculture Organization of the United Nations: Rome, Italy, 2001. 
9. Lidmar-Bergström, K.; Näslund, J.-O. Major landforms and bedrock. In The Physical Geography of Fennoscandia; Seppälä, M., Ed.; Oxford University Press: Oxford, UK, 2005; pp. 3-16.

10. Ebert, A.W. The Role of Vegetable Genetic Resources in Nutrition Security and Vegetable Breeding. Plants 2020, 9, 736. [CrossRef] [PubMed]

11. Ebert, A.W. Potential of Underutilized Traditional Vegetables and Legume Crops to Contribute to Food and Nutritional Security, Income and More Sustainable Production Systems. Sustainability 2014, 6, 319-335. [CrossRef]

12. Høeg, O.F.A. Planter og tradisjon; Universitetsforlaget: Oslo, Norway, 1976.

13. Brandrud, A.S.; Clausen, K. Sluttrapport-Nordatlantiske Delikatesser; Final report-Nordic Delights; Det Kongelige Selskap for Norges Vel: Skjetten, Norway, 2011.

14. Kuoljok, K. Samiska växter i Laponia (Sáme sjatto Laponian, Sámi šattut Laponias; Ájtte: Jokkmokk, Sweden, 2012; ISBN 978-91-87636-21-9.

15. Harlan, J.R.; Wet, J.M.J. Toward a rational classification of cultivated plants. Taxon 1971, 20, 509-517. [CrossRef]

16. Bari, A.; Street, K.; Mackay, M.; Endresen, D.; De Pauw, E.; Amri, A. Focused identification of germplasm strategy (FIGS) detects wheat stem rust resistance linked to environmental variables. Genet. Resour. Crop Evol. 2011, 59, 1465-1481. [CrossRef]

17. Haupt, M.; Schmid, M.W. Combining focused identification of germplasm and core collection strategies to identify genebank accessions for central European soybean breeding. Plant. Cell Environ. 2020, 43, 1421-1436. [CrossRef]

18. Van Zonneveld, M.J.; Scheldeman, X.; Escribano, P.; Viruel, M.; Van Damme, P.; Garcia, W.; Tapia, C.; Romero, J.; Sigueñas, M.; Hormaza, J.I. Mapping Genetic Diversity of Cherimoya (Annona cherimola Mill.): Application of Spatial Analysis for Conservation and Use of Plant Genetic Resources. PLoS ONE 2012, 7, e29845. [CrossRef]

19. Khoury, C.K.; Carver, D.; Barchenger, D.W.; Barboza, G.E.; Van Zonneveld, M.; Jarret, R.; Bohs, L.; Kantar, M.; Uchanski, M.; Mercer, K.; et al. Modelled distributions and conservation status of the wild relatives of chile peppers ( Capsicum L.). Divers. Distrib. 2019, 26, 209-225. [CrossRef]

20. Maxted, N.; Hargreaves, S.; Kell, S.P.; Amri, A.; Street, K.; Shehadeh, A.; Piggin, J.; Konopka, J. Temperate forage and pulse legume genetic gap analysis. Bocconea 2012, 24, 115-146.

21. Hijmans, R.; Spooner, D.M. Geographic distribution of wild potato species. Am. J. Bot. 2001, 88, $2101-2112$. [CrossRef] [PubMed]

22. Maxted, N.; Dulloo, E.; Iriondo, J.M.; Jarvis, A.; Ford-Lloyd, B.V. Gap analysis: A tool for complementary genetic conservation assessment. Divers. Distrib. 2008, 14, 1018-1030. [CrossRef]

23. Ramirez-Villegas, J.; Khoury, C.K.; Jarvis, A.; Debouck, D.G.; Guarino, L. A Gap Analysis Methodology for Collecting Crop Genepools: A Case Study with Phaseolus Beans. PLoS ONE 2010, 5, e13497. [CrossRef] [PubMed]

24. Syfert, M.M.; Castañeda-Álvarez, N.P.; Khoury, C.K.; Särkinen, T.; Sosa, C.C.; Achicanoy, H.A.; Bernau, V.; Prohens, J.; Daunay, M.-C.; Knapp, S. Crop wild relatives of the brinjal eggplant (Solanum melongena): Poorly represented in genebanks and many species at risk of extinction. Am. J. Bot. 2016, 103, 635-651. [CrossRef] [PubMed]

25. Khoury, C.K.; Carver, D.; Kates, H.R.; Achicanoy, H.A.; Van Zonneveld, M.; Thomas, E.; Heinitz, C.; Jarret, R.; Labate, J.A.; Reitsma, K.; et al. Distributions, conservation status, and abiotic stress tolerance potential of wild cucurbits ( Cucurbita L.). Plants People Planet. 2019, 2, 269-283. [CrossRef]

26. Solberg, S.O.; Chou, Y.-Y. Conservation of Indigenous Vegetables from a Hotspot in Tropical Asia: What Did We Learn from Vavilov? Front. Plant. Sci. 2017, 7, 38. [CrossRef]

27. Solberg, S.; Seta-Waken, P.O.; Paul, T.; Palaniappan, G.; Iramu, E. Patterns in the conservation and use of traditional vegetables from the New Guinean biodiversity hotspot. Agroecol. Sustain. Food Syst. 2018, 42, 1079-1091. [CrossRef]

28. GBIF.org. GBIF Occurrence Download. 2020. Available online: https://doi.org/10.15468/dl.cagrkf (accessed on 5 August 2020). [CrossRef]

29. Mossberg, B.; Stenberg, L. Den. nya nordiska floran; Wahlström \& Widstrand: Stockholm, Sweden, 2003.

30. GENESYS. The Global Gateway to Genetic Resources. 2020. Available online: https://www.genesys-pgr.org (accessed on 14 July 2020). 
31. R Core Team. R: A Language and Environment for Statistical Computing; version 3.6.2; CRAN R Project: Vienna, Austria, 2019; Available online: https://r-project.org/ (accessed on 12 May 2019).

32. Chamberlain, S.; Barve, V.; Mcglinn, D.; Oldoni, D.; Desmet, P.; Geffert, L.; Ram, K. Rgbif: Interface to the Global Biodiversity Information Facility Api. 2020. Available online: https:/CRAN.R-project.org/package= rgbif (accessed on 10 June 2020).

33. Hijmans, R.J.; Kapoor, J.; Wieczorek, J.; Garcia, N.; Maunahan, A.; Rala, A.; Mandel, A. DIVA-GIS: Free Spatial Data. 2014. Available online: http://www.diva-gis.org/Data (accessed on 3 June 2014).

34. Fourcade, Y.; Engler, J.O.; Rödder, D.; Secondi, J. Mapping Species Distributions with MAXENT Using a Geographically Biased Sample of Presence Data: A Performance Assessment of Methods for Correcting Sampling Bias. PLoS ONE 2014, 9, e97122. [CrossRef]

35. Clarivate Analytics. Web of Science. Fourth Floor, Philadelphia, PA, USA. 2020. Available online: https://clarivate.com/products/web-of-science/ (accessed on 8 July 2020).

36. Hijmans, R.; Cameron, S.E.; Parra, J.L.; Jones, P.G.; Jarvis, A. Very high resolution interpolated climate surfaces for global land areas. Int. J. Clim. 2005, 25, 1965-1978. [CrossRef]

37. James, G.; Witten, D.; Hastie, T.; Tibshirani, R. An Introduction to Statistical Learning: With Applications in R; Springer: New York, NY, USA, 2013; Volume 103. [CrossRef]

38. Kindt, R. Ensemble species distribution modelling with transformed suitability values. Environ. Model. Softw. 2018, 100, 136-145. [CrossRef]

39. Marmion, M.; Parviainen, M.; Luoto, M.; Heikkinen, R.K.; Thuiller, W. Evaluation of consensus methods in predictive species distribution modelling. Divers. Distrib. 2009, 15, 59-69. [CrossRef]

40. Bradley, A.P. The use of the area under the ROC curve in the evaluation of machine learning algorithms. Pattern Recognit. 1997, 30, 1145-1159. [CrossRef]

41. Freeman, E.A.; Moisen, G. PresenceAbsence: An R Package for Presence Absence Analysis. J. Stat. Softw. 2008, 23, 31. [CrossRef]

42. Jiménez-Valverde, A. Threshold-dependence as a desirable attribute for discrimination assessment: Implications for the evaluation of species distribution models. Biodivers. Conserv. 2014, 23, 369-385. [CrossRef]

43. Liu, C.; White, M.; Newell, G. Selecting thresholds for the prediction of species occurrence with presence-only data. J. Biogeogr. 2013, 40, 778-789. [CrossRef]

44. Carver, D.; Sosa, C.; Khoury, C.; Ramirez-Villegas, J. GapAnalysis: Conservation Indicators Using Spatial Information. R package version 1.0.1. 2020. Available online: https://github.com/ccsosa/GapAnalysis (accessed on 6 August 2020).

45. Olson, D.M.; Dinerstein, E.; Wikramanayake, E.D.; Burgess, N.D.; Powell, G.V.N.; Underwood, E.; Itoua, I.; Strand, H.E.; Morrison, J.C.; D'amico, J.A.; et al. Terrestrial ecoregions of the world: A new map of life on earth. BioScience 2001, 51, 933-938. [CrossRef]

46. UNEP-WCMC. The World Database on Protected Areas (WDPA) Statistics; UNEP-WCMC: Cambridge, UK, 2020; Available online: https://www.protectedplanet.net/ (accessed on 7 May 2020).

47. Dowle, M.; Srinivasan, A. Data Table: Extension of ‘Data.frame'. 2019. Available online: https://CRAN.Rproject.org/package $=$ data.table (accessed on 6 August 2020).

48. Bache, S.M.; Wickham, H. Magrittr: A Forward-Pipe Operator for R. R package version 1.5. 2014. Available online: https://CRAN.R-project.org/package=magrittr (accessed on 6 August 2020).

49. Firke, S. Janitor: Simple Tools for Examining and Cleaning Dirty Data. R package version 2.0.1. 2020. Available online: https:/CRAN.R-project.org/package=janitor (accessed on 6 August 2020).

50. Cayuela, L.; Macarro, I.; Stein, A.; Oksanen, J. Taxonstand: Taxonomic Standardization of Plant Species Names. R package version 2.2. 2019. Available online: https:/CRAN.R-project.org/package=Taxonstand (accessed on 6 August 2020).

51. Wickham, H.; Averick, M.; Bryan, J.; Chang, W.; McGowan, L.D.; François, R.; Grolemund, G.; Hayes, A.; Henry, L.; Hester, J.; et al. Welcome to the Tidyverse. J. Open Source Softw. 2019, 4, 1686. [CrossRef]

52. Bivand, R.S.; Pebesma, E.; Gómez-Rubio, V. Applied Spatial Data Analysis with R, 2nd ed.; Springer: New York, NY, USA, 2013.

53. Pebesma, E. Simple Features for R: Standardized Support for Spatial Vector Data. R J. 2018, 10, 439-446. [CrossRef] 
54. Bivand, R.; Lewin-Koh, N. Maptools: Tools for Handling Spatial Objects. 2019. Available online: https: //CRAN.R-project.org/package=maptools (accessed on 12 June 2019).

55. Hijmans, R.J.; van Etten, J. Raster: Geographic Data Analysis and Modeling. 2020. Available online: https://CRAN.R-project.org/package=raster (accessed on 10 June 2020).

56. Bivand, R.; Keitt, T.; Rowlingson, B. Rgdal: Bindings for the 'Geospatial' Data Abstraction Library. 2019. Available online: https://CRAN.R-project.org/package=rgdal (accessed on 10 October 2019).

57. Hijmans, R.J.; Phillips, S.; Leathwick, J.; Elith, J. Dismo: Species Distribution Modeling. 2017. Available online: https://CRAN.R-project.org/package=dismo (accessed on 10 August 2017).

58. Pateiro-Lopez, B.; Rodriguez-Casal, A. Alphahull: Generalization of the Convex Hull of a Sample of Points in the Plane. 2019. Available online: https://CRAN.R-project.org/package=alphahull (accessed on 12 January 2019).

59. Urbanek, S. rJava: Low-Level R to Java Interface. 2019. Available online: https://CRAN.R-project.org/ package $=$ rJava (accessed on 12 September 2019).

60. Bivand, R.; Rundel, C. rgeos: Interface to Geometry Engine-Open Source ('Geos'). 2019. Available online: https://CRAN.R-project.org/package=rgeos (accessed on 1 October 2019).

61. Wickham, H. Ggplot2: Elegant Graphics for Data Analysis; Springer: New York, NY, USA, 2016; Available online: https://ggplot2.tidyverse.org (accessed on 15 October 2016).

62. Pedersen, T.L. Patchwork: The Composer of Plots. 2019. Available online: https://CRAN.R-project.org/ package=patchwork (accessed on 17 September 2019).

63. Holmboe, J. Nytteplanter og ugraes i Osebergfundet. In Osebergsfundet; Bind, V., Brögger, A.W., Schetelig, H., Eds.; Ukjent Forlag: Oslo, Norway, 1927; pp. 1-78.

64. Zeven, A.C. On the History of Vegetable Gardens in North-west Europe. Bot. J. Scotl. 1994, 46, 605-610. [CrossRef]

65. Lundquist, K. Medeltida klostergrunder på Island-Vegetation och flora, kultur-och reliktväxter, samtida växtnamn; LTJ-fakultetens faktablad 7/2010; Fakulteten för landskapsplanering, trädgårds- och jordbruksvetenskap: Alnarp, Sweden, 2010.

66. Walle, E.M. Preliminary investigations on the introduction of masterwort (Peucedanum ostruthium (L.) W. Koch). Z. Arznei Gewürzpfl 2010, 15, 86-94.

67. Zwirchmayr, J.; Grienke, U.; Hummelbrunner, S.; Seigner, J.; De Martin, R.; Dirsch, V.; Rollinger, J.M. A Biochemometric Approach for the Identification of In Vitro Anti-Inflammatory Constituents in Masterwort. Biomolecules 2020, 10, 679. [CrossRef] [PubMed]

68. Fremstad, E. Masterwort Peucedanum ostruthium in Central Norway. Blyttia 2004, 62, 82-90.

69. Nordstedt, O. Prima loca plantarum suecicarum. Första litteraturuppgift om de i Sverige funna vilda eller förvildade kärlväxterna. Botaniska Notiser 1920, 1-95.

70. Garay, O.A.; Briard, M.; Peron, J.; Planchot, V. Chaerophyllum bulbosum: A new vegetable interesting for its root carbohydrate reserves. Acta Hortic. 2003, 598, 227-234. [CrossRef]

71. Peron, J.; Briard, M. Breeding advances in tuberous-rooted chervil (chaerophyllum bulbosum L.), a new "old vegetable" among the apiaceae. Acta Hortic. 2003, 598, 235-242. [CrossRef]

72. Hämet-Ahti, L. Chaerophyllum bulbosum L. ssp. bulbosum and ssp. prescottii (DC.) Nyman in Finland. Ann. Bot. Fennici 1967, 4, 417-421.

73. Von Linné, C. Carl Linnæi skånska resa år 1749; Wahlström \& Widstrand: Stockholm, Sweden, 1975.

74. Sæther, N.A.H.; Fjellstad, K.B.; Rasmussen, M. Nøkkeltall fra Norsk genressurssenter 2017 Status for bevaringsverdige husdyr, skogtrær og nytteplanter; Norwegian Institute of Bioeconomy Research (NIBIO): Ås, Norway, 2018; Available online: http://hdl.handle.net/11250/2501830 (accessed on 20 January 2018).

75. Zeven, A.; Stemerdink, G. A cluster analysis of eight mediaeval manuscripts based on depicted plant taxa. J. Agr. Tradit. Bot. Appl. 1986, 33, 225-241. [CrossRef]

76. Cas, L.D.; Pugni, F.; Fico, G. Tradition of use on medicinal species in Valfurva (Sondrio, Italy). J. Ethnopharmacol. 2015, 163, 113-134. [CrossRef] [PubMed]

77. Cumo, C. Encyclopedia of Cultivated Plants: From Acacia to Zinnia; ABC-CLIO: Oxford, UK, 2013; pp. $456-460$.

78. Antonious, G.F.; Kochhar, T.S.; Jarret, R.L.; Snyder, J.C. Antioxidants in Hot Pepper: Variation Among Accessions. J. Environ. Sci. Heal. Part B 2006, 41, 1237-1243. [CrossRef]

79. Molbech, C. Henrik Harpestrengs Danske Lægebog fra det trettende Aarhundrede; Ukjent Forlag: Copenhagen, Denmark, 1826. 
80. Lange, J. Kulturplanternes indførselshistorie i Danmark-indtil midten af 1900-tallet; DSR Forlag: Frederiksberg, Denmark, 1999.

81. Åsen, P.A. Plants of possible monastic origin, growing in the past or present, at medieval monastery grounds in Norway. In Plants and Culture: Seeds of the Cultural Heritage of Europe; Morel, J.-P., Mercuri, A.M., Eds.; Edipuglia: Bari, Italy, 2009; pp. 263-276.

82. Pieroni, A.; Giusti, M.E.; De Pasquale, C.; Lenzarini, C.; Censorii, E.; Gonzáles-Tejero, M.R.; Sánchez-Rojas, C.P.; Ramiro-Gutiérrez, J.M.; Skoula, M.; Johnson, C.; et al. Circum-Mediterranean cultural heritage and medicinal plant uses in traditional animal healthcare: A field survey in eight selected areas within the RUBIA project. J. Ethnobiol. Ethnomed. 2006, 2, 16. [CrossRef] [PubMed]

83. Pieroni, A. Local plant resources in the ethnobotany of Theth, a village in the Northern Albanian Alps. Genet. Resour. Crop Evol. 2008, 55, 1197-1214. [CrossRef]

84. Dogan, Y.; Baslar, S.; Ay, G.; Mert, H.H. The Use of Wild Edible Plants in Western and Central Anatolia (Turkey). Econ. Bot. 2004, 58, 684-690. [CrossRef]

85. Dogan, Y.; Nedelcheva, A.M.; Yarci, C. Plant Taxa Used as Brooms in Several Southeast European and West Asian Countries. Nat. Croat. 2009, 17, 193-206.

86. Hadjichambis, A.C.; Paraskeva-Hadjichambi, D.; Della, A.; Giusti, M.E.; De Pasquale, C.; Lenzarini, C.; Censorii, E.; Gonzales-Tejero, M.R.; Sanchez-Rojas, C.P.; Ramiro-Gutierrez, J.M.; et al. Wild and semi-domesticated food plant consumption in seven circum-Mediterranean areas. Int. J. Food Sci. Nutr. 2008, 59, 383-414. [CrossRef]

87. Soukand, R.; Kalle, R. Change in medical plant use in Estonian ethnomedicine: A historical comparison between 1888 and 1994. J. Ethnopharm. 2011, 135, 251-260. [CrossRef]

88. Łuczaj, L.; Pieroni, A.; Tardío, J.; Pardo-De-Santayana, M.; Soukand, R.; Svanberg, I.; Kalle, R. Wild food plant use in 21st century Europe: The disappearance of old traditions and the search for new cuisines involving wild edibles. Acta Soc. Bot. Pol. 2012, 81, 359-370. [CrossRef]

89. Tanaka, T. Tanaka's cyclopaedia of edible plants of the world; Keigaku: Tokyo, Japan, 1976.

90. Rivera, D.; Obón, C.; Heinrich, M.; Inocencio, C.; Verde, A.; Fajardo, J. Gathered Mediterranean Food Plants-Ethnobotanical Investigations and Historical Development. In Local Mediterranean Food Plants and Nutraceuticals; Heinrich, M., Müler, W.E., Galli, C., Eds.; Forum Nutrition Basel Karger: Basel, Switzerland, 2006; Volume 59, pp. 18-74.

91. Ochatt, S.; Jain, S.M. Breeding of Neglected and Under-Utilized Crops, Spices and Herbs; Science Publishers, Inc.: Enfield, NH, USA, 2007.

92. Keatinge, J.; Chadha, M.L.; Hughes, J.D.; Easdown, W.J.; Holmer, R.J.; Tenkouano, A.; Yang, R.Y.; Mavlyanova, R.; Neave, S.; Afari-Sefa, V.; et al. Vegetable gardens and their impact on the attainment of the Millennium Development Goals. Biol. Agric. Hortic. 2012, 28, 71-85. [CrossRef]

93. Nierenberg, D. Agriculture: Growing food-And solutions. In State of the World. Is Sustainability Still Possible? Assadourian, E., Prugh, T., Eds.; Island Press: Washington, DC, USA; Covelo, CA, USA; London, UK, 2013; pp. 190-200.

94. Kahane, R.; Hodgkin, T.; Jaenicke, H.; Hoogendoorn, C.; Hermann, M.; Keatinge, J.D.A.; Hughes, J.D.; Padulosi, S.; Looney, N. Agrobiodiversity for food security, health and income. Agron. Sustain. Dev. 2013, 33, 671-693. [CrossRef]

(C) 2020 by the authors. Licensee MDPI, Basel, Switzerland. This article is an open access article distributed under the terms and conditions of the Creative Commons Attribution (CC BY) license (http://creativecommons.org/licenses/by/4.0/). 